after 72 hours was also negative. At this stage the child began to regain consciousness, and by the end of a week he was perfectly well and running about the ward. The mother, when she came to take the child home, was told that he certainly had not had tuberculous meningitis or any other form of tubercle, but that the cause of the coma, from which he had now recovered completely, remained undiagnosed.

The usual hospital summary of the case was in due course made and a copy sent to the general practitioner, who received the notification about 10 days after the patient's discharge. $\mathrm{He}$ at once telephoned the hospital in great alarm to say that he had just received the discharge summary with its diagnosis 'Coma, cause undetermined, with complete recovery'. About 3 days after the child had been discharged the doctor had been summoned to the home by the mother, who showed him the body of the dead boy. She told him that the hospital had confirmed her suspicion of tuberculous meningitis, and had let her take the child home to die. The doctor had accordingly signed a death certificate with this diagnosis and the child had been duly buried the next day. Only when the general practitioner received the discharge summary from the hospital did he realise that he had been duped by the mother.

The doctor had only recently started in that practice, and knew nothing of the previous family history. Medical records at the end of the war were often nonexistent. The mother had told him she was epileptic and that she was dependent on phenobarbitone, so he had agreed to supply her with this drug.

It was now abundantly clear that the child's coma had been due to poisoning by the mother, presumably with barbiturates to which she had access, and that she had finally succeeded in murdering the child by the same method.

To prove this would have been difficult; the mother had no other children alive and her age was such that further pregnancy was unlikely. After a great deal of debate, it was decided to do nothing further.

\title{
Prolactin deficiency, obesity, and enlarged testes - a new syndrome?
}

\author{
ABRAHAM ROITMAN, SARAH ASSA, RIVKA KAULI, AND ZVI LARON \\ Institute of Paediatric and Adolescent Endocrinology, Beilinson Medical Centre, Petah Tikva, and the \\ Sackler School of Medicine, Tel Aviv University, Israel
}

SUMMARY A 4-year-old boy is described who was obese and slightly mentally retarded. His testes were enlarged. The only endocrine disorder present was a failure to increase plasma prolactin after stimulation.

Prolactin deficiency not associated with deficiency of other pituitary hormones is rare. It has been reported in 2 women with failure of lactation, ${ }^{1}$ in 2 families with pseudohypoparathyroidism, ${ }^{2}$ and in a boy whose growth and sexual development were retarded. ${ }^{3}$ We describe an obese child with pro-

Abbreviations:
11-OHCS:
11-hydroxycorticosteroids
T4:
TSH: thyroxine
TRH: thyroid-stimulating hormone LH-RH: luteinising hormone-releasing hormone
FSH:

lactin deficiency and enlarged testes in whom the clinical findings were entirely different.

\section{Case report}

The infant was referred at age one year because of excessive obesity and bulimia (hyperphagia) which had been present at birth and had thereafter progressed steadily. His birthweight had been $4160 \mathrm{~g}$. At 7 months he had weighed $11.9 \mathrm{~kg}$, and at 4 years his weight reached $27 \mathrm{~kg}$ (10 kg above 50th centile), with skinfolds measuring $24 \mathrm{~mm}$ (triceps) and $17 \mathrm{~mm}$ (subscapular). Linear growth was consistently on the 75th centile with a slight bone age retardation. His mental development was also slightly retarded. Apart from obesity, the main finding was the enlargement of the testes $(3-4 \mathrm{ml})$ (Figure); this was neither progressive nor was it associated with any other sign of sexual precocity. A thorough investigation of the central nervous system, including at age 4 years a computerised tomography scan, showed no disease. Routine tests of blood chemistry (including calcium and 


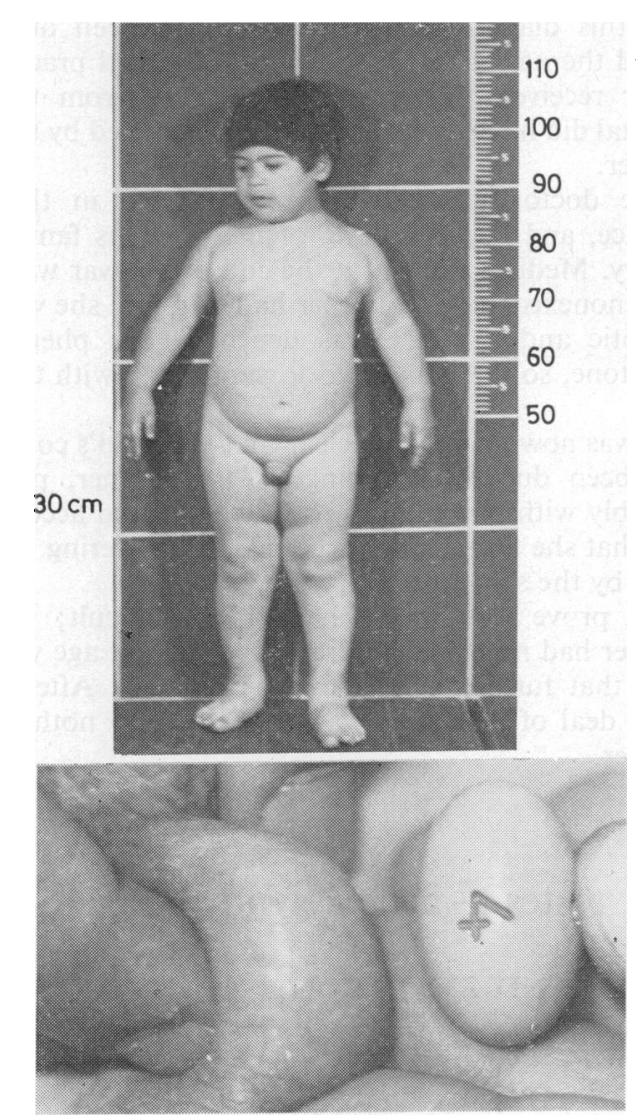

Figure A 4-year-old boy with hypoprolactinaemia, obesity, and enlarged testes. (The testes were equivalent to size 4 of the Prader orchidometer.)

phosphorus levels), and urine analysis, gave normal results.

Endocrinological investigation gave normal values of plasma growth hormone (peak response $>20$ $\mathrm{ng} / \mathrm{ml}$ after insulin hypoglycaemia), and normal cortisol secretion (11-OHCS rose from 10 to 16 $\mu \mathrm{g} / 100 \mathrm{ml}$ in the same test). Levels of $\mathrm{T} 4$ were repeatedly found to be in the low to normal range: 4.9 to $6.9 \mu \mathrm{g} / 100 \mathrm{ml}(63$ to $89 \mathrm{nmol} / \mathrm{l})$, normal $4 \cdot 7$ to $11 \cdot 6 \mu \mathrm{g} / 100 \mathrm{ml}(61$ to $151 \mathrm{nmol} / \mathrm{l})$, and the ${ }^{131}$ I uptake was slightly low (13\% at 24 hours). At age $19 / 12$ years the TSH response to TRH was normal $(7 \cdot 3$ to $16 \cdot 2 \mu \mathrm{U} / \mathrm{ml})$ but on two later occasions it was fairly low $(1.5$ to 3.6 and 1.8 to $7 \mu \mathrm{U} / \mathrm{ml}$ ). In tests performed between $23 / 12$ and 4 years, the response of plasma LH to intravenous $\mathrm{LH}-\mathrm{RH}\left(50 \mu \mathrm{g} / \mathrm{m}^{2}\right)$ was adequate, but the FSH rose from normal basal levels to high levels of $4 \cdot 1,4 \cdot 5$, and $7 \cdot 8 \mathrm{mU} / \mathrm{ml}$ (normal values for pre-
Table Prolactin secretion in a child with obesity and enlarged testes

\begin{tabular}{|c|c|c|c|}
\hline \multirow[t]{2}{*}{ Test } & \multirow[t]{2}{*}{ Age (months) } & \multicolumn{2}{|l|}{ Prolactin $(\mathrm{ng} / \mathrm{ml})$} \\
\hline & & Basal & Peak \\
\hline Basal levels & 19 to 43 & $\begin{array}{c}2 \cdot 5 ; 3 \cdot 0 ; 1 \cdot 3 ; \\
0 ; 1.4 ; 4.4\end{array}$ & - \\
\hline TRH* $^{*}$ & 19 & 2.9 & $4 \cdot 5$ \\
\hline TRH* $^{*}$ & 39 & $2 \cdot 3$ & $2 \cdot 8$ \\
\hline ITT - TRH $\dagger$ & 46 & 0.7 & $1 \cdot 2$ \\
\hline Metoclopramideł & 39 & 1.5 & $5 \cdot 8$ \\
\hline Metoclopramide $* *$ & 46 & 0 & $1 \cdot 5$ \\
\hline Metoclopramide** & 46 & 0 & $3 \cdot 8$ \\
\hline
\end{tabular}

pubertal boys in our laboratory are up to $3 \mathrm{mU} / \mathrm{ml}$ ). There was also an exaggerated response of plasma testosterone to the administration of human chorionic gonadotrophin (1500 units $\times 3$, given on alternate days) with levels rising from 19 to 300 $\mathrm{ng} / 100 \mathrm{ml} ; 0 \cdot 6-10 \cdot 5 \mathrm{nmol} / 1$ (normal values for prepuberty in our laboratory are up to $180 \mathrm{ng} / 100 \mathrm{ml}$; $6.3 \mathrm{nmol} / \mathrm{l})$. The most striking endocrinological finding was the very low secretion of prolactin (determined by radioimmunoassay) as shown in repeated tests (Table). After stimulation, a normal response is a rise of plasma prolactin of at least $10 \mathrm{ng} / 100 \mathrm{ml}$, in most instances $>15 \mathrm{ng} / 100 \mathrm{ml}$.

The father, mother, and the younger brother of our patient were slightly obese, with normal blood glucose levels. Their plasma T4 levels were $7 \cdot 4$, $8 \cdot 6$, and $10 \cdot 4 \mu \mathrm{g} / 100 \mathrm{ml}(96,114,135 \mathrm{nmol} / \mathrm{l})$, the peak TSH levels after TRH were 14.5, 19, 22.5 $\mu \mathrm{U} / \mathrm{ml}$, and the peak prolactin levels in the same test were $22 \cdot 8,38 \cdot 8$, and $20 \mathrm{ng} / 100 \mathrm{ml}$ respectivelythat is normal values.

\section{Discussion}

The child we describe proved to have a clear deficiency of prolactin, as shown by stimulation tests aimed at the hypothalamic level (hypoglycaemia), the pituitary level (TRH), and both levels (metoclopramide). The endocrinological investigation showed that prolactin was the only pituitary hormone lacking, although a slight disorder along the TSH axis was suspected.

Testicular enlargement with primary hypothyroidism associated with hyperprolactinaemia is a well known syndrome. ${ }^{4}$ In our case it was interesting to find an enlargement of the testes associated with thyroid function in the low to normal range, and hypoprolactinaemia. The response of testosterone to human chorionic gonadotrophin showed that this enlargement was a result of early testicular activation, probably due in turn to early activation 
of the gonadostat, as shown by the greater response of FSH to LH-RH.

A connection between obesity and disturbances of circadian rhythm of prolactin has been reported in women, ${ }^{5}$ but it is difficult to judge the relevance of this observation to our case.

While the obesity with bulimia and the early gonadal activation point to a hypothalamic disturbance, the low prolactin and, perhaps, the TSH response to TRH would more logically point towards a pituitary disorder, the lactotrophic cells being either absent or unresponsive. As it is unlikely that the hypothalamic and the pituitary disorders are not interrelated, it is tempting to explain the low pituitary prolactin secretion as originating from a hypothalamic disturbance. There are several possibilities. (1) A deficient TRH secretion. A high and delayed TSH response to TRH would have been expected as is usual in hypothalamic disturbances, but the contrary was observed in our patient. (2) An excessive prolactin inhibitory factor (dopamine) secretion. The lack of significant rise of prolactin after the potent antidopaminergic agent metoclopramide argues against this possibility. (3) A deficient secretion of the still hypothetical prolactin releasing factor. (4) A developmental defect of lactotrophic cells due to a fetal hypothalamic disturbance. The early onset of the disorder fits this possibility but the normal prolactin secretion found in anencephaly ${ }^{6}$ makes it less likely. (5) In view of the known central nervous system actions of TRH and its wide distribution in the brain, it may serve as a central neurotransmitter. ${ }^{7}$ Its high concentration in the hypothalamus suggests that it could act directly on the hypothalamic centres. It could be that in our patient the receptors mediating such action are defective, together with similar receptors mediating the TRH action on the pituitary cells secreting prolactin and TSH.

The high birthweight, large testes, and slight mental retardation suggest a possible relationship between the syndrome described and the reported $\mathrm{X}$-linked syndrome of mental deficiency and megalotestes. ${ }^{8}$ However, obesity is not generally a feature of this syndrome and no clear endocrine disturbance was found; the prolactin secretion has yet to be determined.

In conclusion this child appears to show features of a hypothalamic-pituitary syndrome hitherto undescribed.

\section{References}

1 Turkington $\mathbf{R} \mathbf{W}$. Phenothiazine stimulation test for prolactin reserve: the syndrome of isolated prolactin deficiency.J Clin Endocrinol Metab 1972; 34: 247-9.

2 Carlson H E, Brickman A S, Bottazzo G F. Prolactin deficiency in pseudohypoparathyroidism. N Engl J Med 1977; 296: 140-4.

3 Spitz I M, Landau H, Almaliach U, Rosen E, Brautbar N, Russell A. Diminished prolactin reserve: a case report. $J$ Clin Endocrinol Metab 1977; 45: 412-8.

4 Roitman A, Assa S, Laron Z. Hyperprolactinaemia in a boy with hypothyroidism due to an ectopic thyroid. Acta Paediatr Belg 1978; 31 : 155-7.

5 Copinschi G, Vanhaelst L, Robyn C, et al. In: Klotz $\mathrm{H}$ P, ed. Les endocrines et le milieu. Paris: Expansions Scientifiques, 1975: 193-208.

- Aubert M L, Grumbach S L, Kaplan S L. The ontogenesis of human fetal hormones. III. Prolactin. J Clin Invest 1975; 56: 155-64.

7 Schally A V, Arimura A. Physiology and nature of hypothalamic regulatory hormones. In: Martin L, Besser $G \mathrm{M}$, eds. Clinical neuroendocrinology. New York: Academic Press, 1977: 9-10.

8 Ruvalcaba R H A, Myhre S A, Roosen-Runge E C, Beckwith J B. $X$-linked mental deficiency megalotestes syndrome. JAMA 1977; 238: 1646-50.

Correspondence to Professor Z Laron, Institute of Paediatric and Adolescent Endocrinology, Beilinson Medical Centre, Petah Tikva, Israel. 